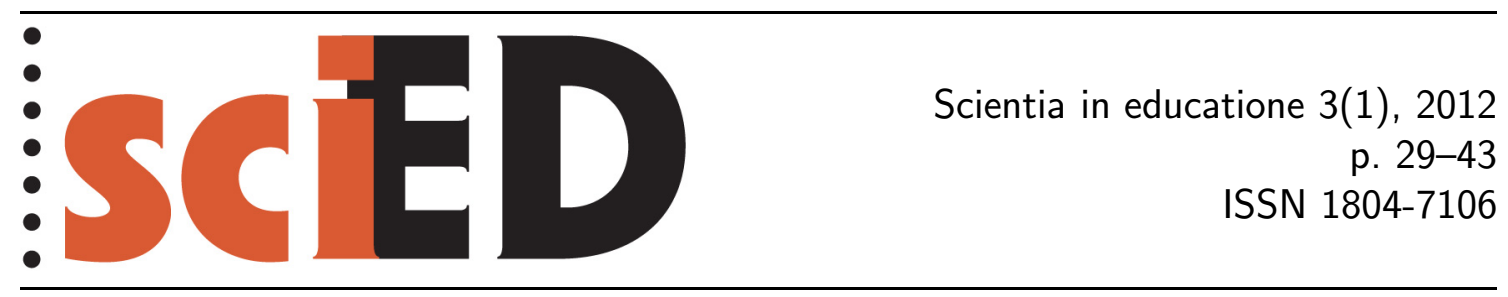

\title{
Efektivita zařazování PowerPointových prezentací do výuky obecné chemie
}

\author{
Klára Urbanová
}

\begin{abstract}
Abstrakt
V letech 2006-2010 byl realizován výzkum týkající se využití prezentací v programu PowerPoint ve výuce obecné chemie. Především byl zaměřen na hledání takové formy prezentací, které přinesou do výuky potřebnou názornost, interaktivitu a zvýší tak její efektivitu. Zároveň se soustředil na eliminaci možných negativních dopadů tohoto didaktického prostředku na edukační proces. Tento článek shrnuje teoretická východiska práce, stručný popis metodologie výzkumu, diskusi výsledků a závěry. Podrobněji se dotýká vyhledávání a posuzování volně stažitelných prezentací určených pro výuku chemie.
\end{abstract}

Klíčová slova: didaktické prezentace, dotazníkové šetření, didaktický test, prrírodovědné vzdělávání, názornost výuky.

\section{Efficiency of Using PowerPoint Presentations in the Teaching of General Chemistry}

\begin{abstract}
In the years 2006-2010 the research has been conducted on the use of PowerPoint presentations in the general chemistry teaching. Primarily it focused on the search for the form of presentation that will bring needed clarity to the teaching and will increase the effectiveness of teaching. It also focused on the elimination of possible negative effects of the presentations on the educational process. This article summarizes the theoretical background of the work, a brief description of research methodology and discussion of results and conclusions. It presents in detail the part of research focused on finding and assessing freely downloadable presentations for teaching chemistry.
\end{abstract}

Key words: didactic presentations, questionnaire investigation, didactic test, science education, clarity of teaching. 


\section{1 ÚVOD}

Do oblasti vzdělávání v posledních 10 letech výrazně zasáhl rychlý vývoj informačních a komunikačních technologií. Technické vybavení, které bylo před pěti lety pro školy luxusem, se dnes stává samozřejmostí a na trh přicházejí stále nové nebo vylepšené technické didaktické prostředky. Výzkum, o němž pojednává tento článek, byl proto zaměřen na dvě oblasti a jejich vzájemné propojení. Z hlediska chemie je zaměřena na oblast obecné chemie a řešení problémů spojených s její výukou. Tato část učiva není často oblíbená nejen mezi žáky, ale dokonce ani mezi učiteli. Pro učitele je obtížná jak obsahově, tak z hlediska didaktického. Pro žáky je náročná na porozumění, což souvisí s nízkou schopností aplikace poznatků obecné chemie $\mathrm{v}$ dalších částech učiva chemie. Z těchto důvodů by možná právě zde mohly ke zvýšení efektivity přispět některé didaktické prostředky, jako jsou například prezentace vytvořené v programu PowerPoint.

\section{CÍLE VÝZKUMU}

Hlavním cílem tohoto výzkumu bylo nalézt vhodnou formu prezentací určených pro výuku tak, aby žáci při výuce doplněné prezentacemi byli aktivně zapojeni do výuky a spolupodíleli se na tvorbě znalostí, vědomostí a dovedností z oblasti obecné chemie. Součástí hlavního cíle práce bylo dále vytvořit soubor prezentací zahrnujících učivo obecné chemie pro střední školy tak, aby žáci byli schopni tématu aktivně porozumět a díky tomu získané znalosti, vědomosti a dovednosti využívat ve studiu dalších oblastí chemie

\subsection{TEORETICKÝ ZÁKLAD VÝZKUMU}

V první etapě výzkumné práce bylo vytvořeno deset prezentací z oblasti obecné chemie. Tyto prezentace byly tvořeny především na základě informací získaných z různých výzkumů, týkajících se jednak přímo PowerPointových prezentací, ale zároveň i prací, které se zabývaly vlivem grafiky a prvků užívaných ve výukových materiálech na pozornost žáků a efektivitu výuky. Z některých doporučení pro tvorbu prezentací, které je možno získat například při výuce informatiky na středních či vysokých školách, bylo možno vycházet pouze částečně, po formální stránce. Důvodem je především to, že tato výuka (případně i různá komerční školení) je zaměřena na tvorbu prezentací zcela jinými účely, než výukovými. A právě proto, že řada tvůrců vychází z těchto doporučení, nelze často o prezentacích, které jsou ve výuce využívány, tvrdit, že jsou didaktické.

Z odborných výzkumů, ze kterých práce vycházela, lze uvést např́íklad práce Bartsche a Coberna (2003), kteří se věnovali využití obrázků v prezentacích a snažili se odpovědět na otázku, zda má větší vliv na zapamatování informací pouze text, text doplněný obrázkem, který nesouvisí přímo s tématem, či obrázkem relevantním. Dále je možno jmenovat práci Priestlyho (1991), ve které autor diskutuje použití různých fontů, možností zvýraznění textu, barevnost textu, použití malých a velkých písmen atd. Tato práce vychází z několika výzkumů v oblasti typografie. Autor zde např́k lad dokládá pozitivní vliv na pozornost čtenáře při použití malých písmen oproti velkým písmenům apod.

Učivo do prezentací bylo z hlediska obsahu vybíráno na základě pojmové analýzy, která zde musela zahrnovat i posouzení, která témata jsou vhodná pro tento způsob zpracování a která ne. K uspořádání učiva v prezentacích byla použita me- 
toda orientovaných grafi̊, kterou popisuje Ctrnáctová (1981, 1998). Tato metoda je vhodná především při vytváření nových materiálů a hledání logických souvislostí mezi pojmy.

\subsection{PosOuZEní ÚROVNĚ VOLnĚ DOSTUPNÝCH ČESKY}

\section{A ANGLICKY PSANÝCH PREZENTACÍ Z OBECNÉ CHEMIE}

Jedním z mnoha kroků při teoretických přípravách výzkumu bylo vyhledávání a posuzování úrovně prezentací na vybrané téma, které mají učitelé možnost najít, stahovat a dále použít v nalezené podobě nebo dle svého uvážení upravovat. Relevantní prezentace byly jednak hledány na místech, kde je možné očekávat shromažd’ování výukových materiálů (např. RVP portál, webové stránky pracovišt zaměřených na didaktiku chemie apod.). Dále byla do vyhledavačů zadávána klíčová slova vybraná $\mathrm{z}$ daného učiva $\mathrm{v}$ češtině a angličtině a hledány soubory uložené na internetu ve formátu .ppt nebo .pdf. Takto nalezené prezentace pak byly posuzovány především z hlediska dodržení požadavků kladených na tento typ materiálů, tak aby vykazovaly patřičnou didaktickou úroveň a přínos výuce chemie.

\subsection{DotAZNíkOvÉ ŠETřEní}

Po vytvoření prvního souboru prezentací byli vyzváni učitelé, kteří měli zájem začlenit prezentace do výuky, aby se zúčastnili semináře, ve kterém jim byly tyto prezentace představeny a byly jim zodpovězeny dotazy, které se týkaly práce s prezentacemi ve výuce. Již tato fáze výzkumu přinesla první informace, přestože byla především fází přípravnou. Podstatný zde byl přimý kontakt s vyučujícími, jejich reakcemi a dotazy. Asi po měsíci byly k dispozici první reakce učitelů, zjištované formou dotazníkového šetření.

\subsection{DIDAKTICKÝ TEST}

Po třech letech od zahájení výzkumu, kdy byly prezentace formou seminářů učitelům představeny a dány $\mathrm{k}$ dispozici, proběhla závěrečná fáze výzkumné práce ověřování vlivu prezentací na efektivitu výuky pomocí didaktických testů mezi žáky. Pro testování ve třídách byli osloveni učitelé, kteří se zúčastnili v roce 2006 seminářo̊, na kterých jim byly poskytnuty prezentace na téma Struktura látek a kteří následně odevzdali vyplněné dotazníky. Z nich pak byli vybráni ti, kteří poskytnuté prezentace po celou dobu ve výuce používali, tak aby se co nejvíce eliminoval vliv nezkušenosti práce s tímto didaktickým prostředkem. Jako srovnávací byl pak vybrán vzorek podobné velikosti. Třídy byly vybrány z obdobných typů škol a oblastí.

\section{PRŮBĚH VÝZKKUMNÉ PRÁCE}

\subsection{TVORBA PREZENTACÍ - STANOVENÍ POŽADAVKU゚ NA DIDAKTICKOU PREZENTACI}

Při tvorbě prezentací bylo nutné zohlednit již výše zmiňované poznatky z oblasti typografie a psychologie, dávající do souvislostí zrakové vnímání verbálních i neverbálních informací a schopnosti zapamatování a učení. 
Úloha:

-Sestavte modely molekul:

\begin{tabular}{|l|l|l|l|l|}
\hline 1) $\mathrm{CCl}_{4}$ & $2) \mathrm{CO}_{2}$ & $3 \mathrm{PCl}_{5}$ & $4) \mathrm{BF}_{3}$ & $5) \mathrm{SF}_{6}$ \\
\hline
\end{tabular}

-Prĭ̌adte tvarům molekul názwy: "LINEÁRuí MOLEKULA -ROVHOSTRAHHÝ TROJÚHELHÍK

-TETREDR (=pravidelný čtyřstěn)

-TRIGONÁLHÍ BIPYRAMIDA (=trojboký dwojjehlan)

-OKTAEDR (=pravidelný osmistěn)

-K jednotliøým názvům si načrtněte prĩslušný tvar.

Obr. 1: Ukázka z prezentace - Stavba látek - zadání úkolu

\section{Základni tvary molekul: (Řešení předchozi úlohy)}

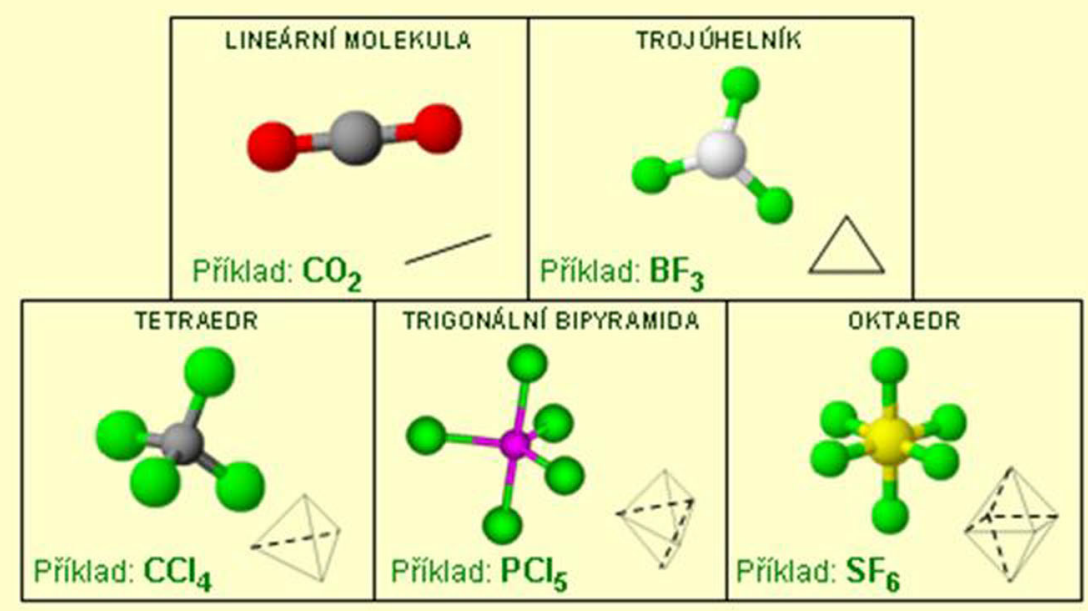

Obr. 2: Ukázka z prezentace - Stavba látek - řešení úkolu

Další velmi důležitou částí tvorby prezentací byla motivace žáků. Pro její podporu je zařazeno do prezentace množství fotografí́, modelů a animací, které by zároveň měly přispívat $\mathrm{k}$ lepšímu porozumění učivu. Dále jsou do prezentací zařazovány úlohy, které vychází z předchozích zkušeností a znalostí žáků nebo např. z práce s modely (ukázka - obr. 1).

Aktivizace žáků je při užití prezentací velmi žádoucí. Výuka s použitím PowerPointových prezentací obvykle svádí žáky k určité pasivitě - např. Craig a Amernic (2006) uvádí, že „prezentace činní studenty spíše pasivně zaneprázdněnými než aktivně zapojenými“. Aktivizujícími prvky v prezentacích a jejich vlivem na účinnost 
didaktického prostředku se zabýval výzkum zapojující do prezentací Content-Based Questions (CBQs - otázky vyplývající z obsahu) (Gier, Kreiner, 2009). Výsledky ukázaly významně vyšší testové a zkouškové skóre při užití CBQs ve srovnání s použitím pouze tradiční přednášky s PowerPointem a tištěnými podklady.

\subsection{ZDROJE A ÚROVEŇ PREZENTACÍ Z OBECNÉ CHEMIE}

Nejběžnějším zdrojem získávání prezentací bývá pro pedagogy internet. Jednak lze hledat zdroje na portálech středních škol (př. http://www.jaroska.cz/elearning/ chemie/index.html - Gymnázium Brno) nebo jejich učitelů (př. webové stránky Michaela Canova http://www.jergym.hiedu.cz/ canovm - Gymnázium Liberec). Ideálním zdrojem materiáli̊ mohou být webové stránky při vysokých školách, především těch, které připravují budoucí učitele. Např. portál http://www.studiumchemie.cz při Př́rodovědecké fakultě UK, nebo http://www.ped.muni.cz/wchem/materialy.html Pedagogické Fakulty MU. Materiály na takových stránkách bývají ověřené a kvalitní po chemické i didaktické stránce. Na zahraničních stránkách je to obdobné. Jedná se o materiály konkrétních pedagogů či institucí, které vznikají jako podpora výuky chemie, popřípadě př́ŕrodovědných oborů obecně.

Proto nás zajímalo, zda se na těchto serverech najdou mezi materiály i PowerPointové prezentace zpracovávající učivo obecné chemie a pokud ano, tak jaký je způsob zpracování, zda obsahuje dostatek grafických prvků zvyšujících názornost učiva a zda obsahují aktivizační prvky pro žáky či studenty.

Dále jsou uváděny ukázky vybraných prezentací, jejich popis a zdroj. Na internetu je samozřejmě vyvěšeno nepřeberné množství prezentací určených do výuky. Následující ukázky byly vybrány tak, aby z hlediska typu a zdroje byly reprezentativním vzorkem toho, co lze nalézt a stahovat. Tyto ukázky a popis mohou sloužit i jako doporučení, jakým způsobem na prezentace, které se nám dostanou do ruky nahlížet a čeho si všímat, než se je rozhodneme použít.

\section{PřEHLED POSUZOVANÝCH PREZENTACÍ VOLNĚ DOSTUPNÝCH NA INTERNETU}

\section{AwESOME SCIENCE TEACHER RESOURCES}

http://www.nclark.net/Chemistry

Tyto stránky vytváří nyní středoškolská, dříve vysokoškolská učitelka Nancy Clark. Uvedený web je určen pro učitele př́rodovědných předmětů vysokých a středních škol. Lze zde nalézt:

- PowerPointové prezentace

- Pracovní listy

- Laboratorní cvičení

- Odkazy na užitečné stránky

- Puzzle, hry a písničky

- Online testy 

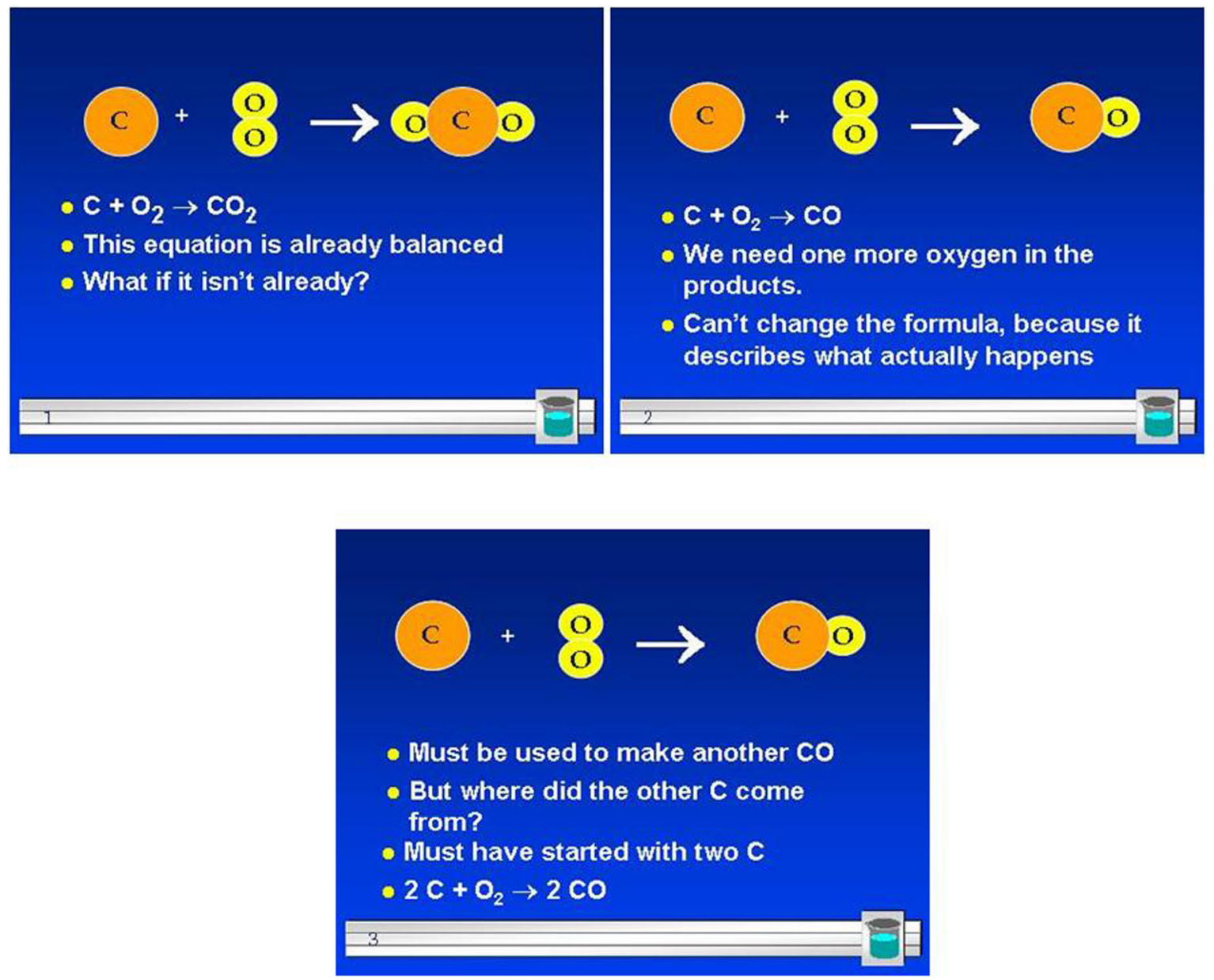

Obr. 3: Prezentace z internetových stránek Awesome science teacher resources

Na obrázku 3 je ukázka snímku z jedné z prezentací, zaměřených na obecnou chemii. Snímky nejsou nijak graficky bohaté. Jediným názorným výukovým grafickým prvkem jsou dvourozměrné modely molekul. Informace jsou na snímcích pouze předkládány, nenalezneme zde žádné prvky, které by vedly k aktivní činnosti žáků (žák např. nemusí žádné informace sám odvozovat).

\section{Chemistryland - Ken Costello}

http://www.chemistryland.com/home.html http://www.chemistryland.com/CHM130/chm130home.html

Chemistryland jsou stránky, kde lze nalézt ucelené kurzy z oblasti chemie. Instruktor Ken Costello zde využívá PowerPointových prezentací a zároveň zde uvádí svá doporučení, jak PowerPoint ve výuce využívat. Silně kritizuje využívání PowerPointu jako prostředku ke spouštění textů a hovoří zde o možnostech prezentací, jak představit žákům problém a pak ho řešit. Prezentace na uvedených stránkách dobře využívají možnost zařazení obrázků a animací graficky názorných výukových prvků. Prezentace obsahují i otázky k přemýšlení pro žáky a ty jsou graficky řešeny. Ukázky snímků jsou na obrázku 4. 

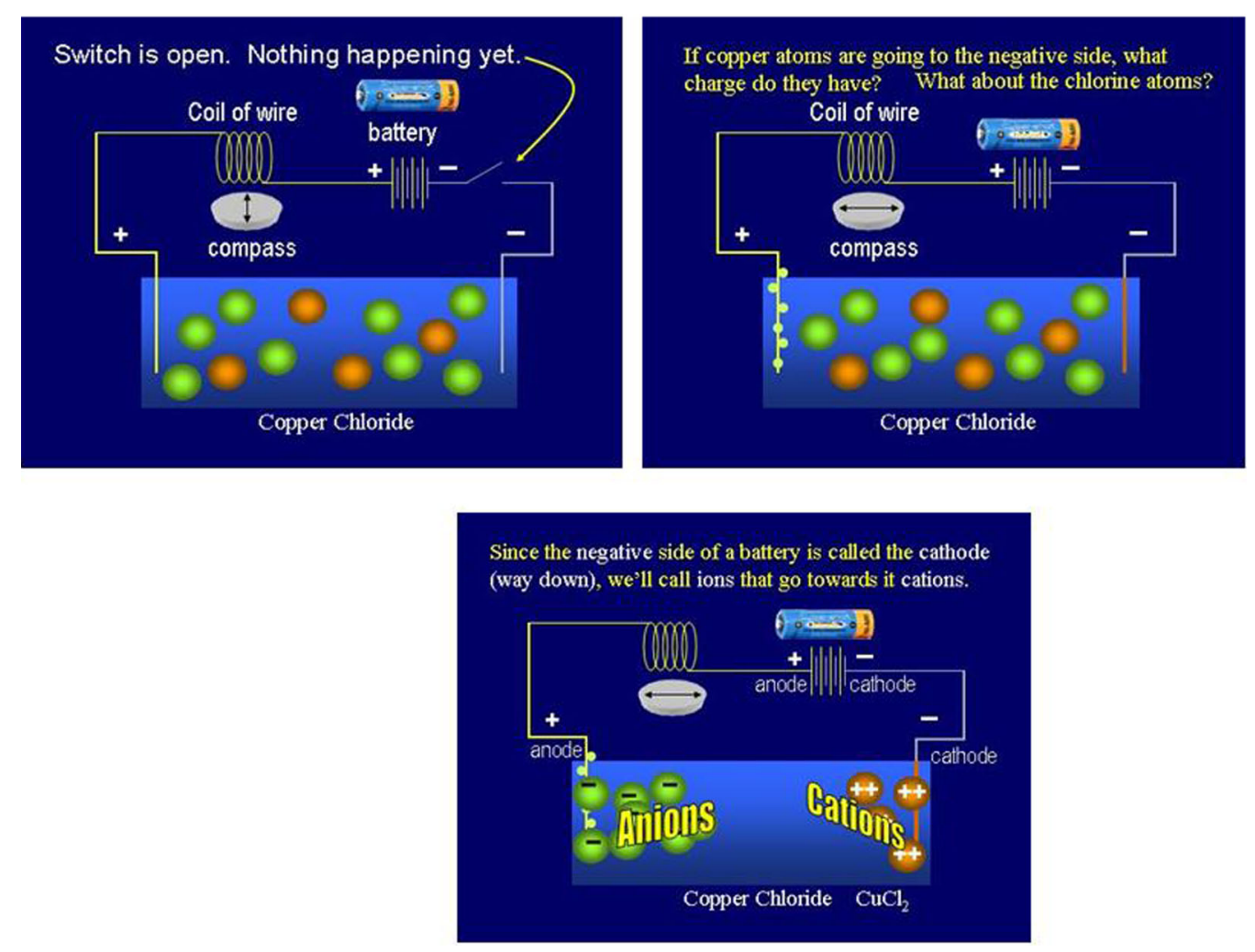

Obr. 4: Prezentace z internetových stránek Chemistryland

\section{ChalkBored}

http://www.chalkbored.com/lessons/chemistry-11.htm http://www.chalkbored.com/lessons/chemistry-12.htm

Na této stránce lze nalézt zdroje materiálů pro středoškolskou výuku chemie: pracovní listy, laboratorní práce, texty a PowerPointové prezentace.

Prezentace umístěné na těchto stránkách (ukázka - obr. 5) využívají velmi málo graficky názorných výukových prvků (tabulky, barevnost, šipky). Navíc prezentace nesplňují základní požadavky na přehledné didaktické prezentace. Texty jsou nahuštěné, pro tento typ prezentace učiva nevhodné, jednotlivé snímky nejsou přehledně členěné.

\section{Extending Acid/Base Concepts}

1 a) proton, hydronium, $\mathrm{H}_{3} \mathrm{O}^{+}$

b) all release $\mathrm{H}^{+}$: mono $=$releases $1 \mathrm{H}^{+}$, poly $=$ more than $1, \mathrm{di}=\mathrm{two}$, tri $=$ three

c) Neutralization

\begin{tabular}{|c|c|c|}
\cline { 2 - 3 } \multicolumn{1}{c|}{ 1d), 2a) } & Acid & Base \\
\hline $\begin{array}{c}\text { Arrhenius } \\
\text { (grade } \\
11 \text { ) }\end{array}$ & $\begin{array}{c}\text { Produces } \mathrm{H}^{+} \text {in } \\
\text { solution } \\
\mathrm{HCl} \rightarrow \mathrm{H}^{+}+\mathrm{Cl}^{-}\end{array}$ & $\begin{array}{c}\text { Produces } \mathrm{OH}^{-} \text {in } \\
\text { solution }\end{array}$ \\
\hline Bronsted & $\mathrm{H}+$ donor & $\mathrm{H}+$ acceptor \\
& & $\mathrm{HCl}+\mathrm{OH}^{-}+\mathrm{NaOH}^{+}$
\end{tabular}

$2 \mathrm{~b})$ i) there is no water/solution, thus aqueous ions do not form (no $\mathrm{H}^{+}$or $\mathrm{OH}^{-}$)
Extending Acid/Base Concepts 2b) ii) diagram as on pg. 418<smiles>Clc1ccccc1</smiles>

iii) $\mathrm{HCl}$ is an acid because it donates $\mathrm{H}^{+}$, $\mathrm{NH}_{3}$ accepts $\mathrm{H}^{+}$and therefore is the base $\left(\mathrm{NH}_{4}{ }^{+}\right.$and $\mathrm{Cl}^{-}$then form an ionic compound)

3a) Lewis acid: electron pair acceptor Lewis base: electron pair donor

$3 b)$ the Lewis definition is universal because Arrhenius and Bronsted are special cases (as above or in reaction on pq. 428)

Obr. 5: Prezentace z internetových stránek Chalkboard 


\section{Education Using PowerPoint}

http://www.educationusingpowerpoint.org.uk/

Tento web si klade za cíl vytvářet vysoce kvalitní PowerPointové prezentace a další zdroje pro výuku fyziky, chemie a biologie v souladu s novými požadavky na obsah vzdělávání ve Velké Británii. Obsahuje také animace a jiné zdroje. Autoři zde uvádí, že všechny tyto prostředky mohou být použity na interaktivních tabulích.

Tyto prezentace (ukázka obr. 6) jsou graficky velmi bohaté na názorné výukové prvky a obsahují i aktivizující prvky pro žáky. Ze všech uváděných příkladů se nejvíce blíži naší představě o kvalitní didaktické prezentaci.
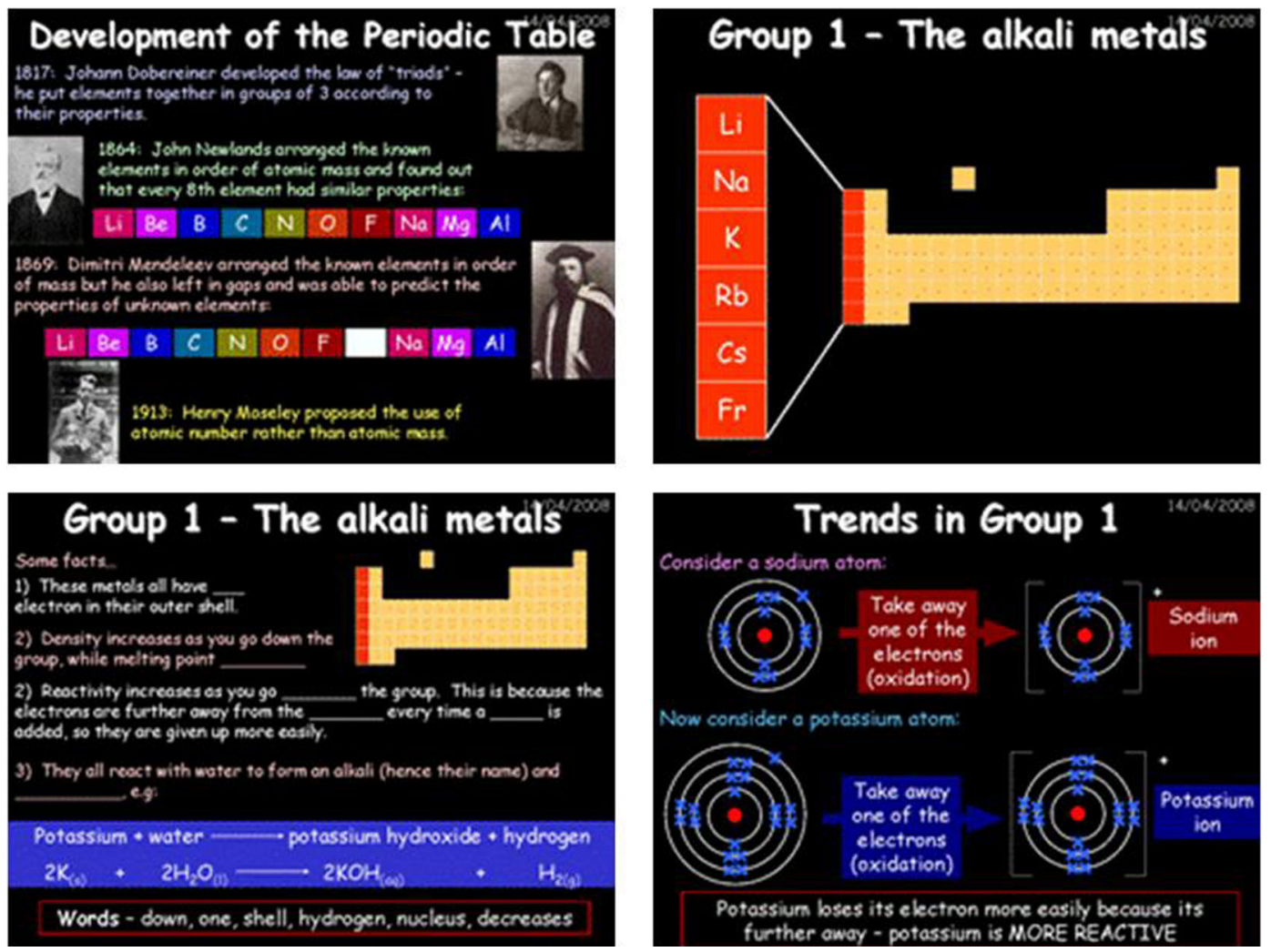

Obr. 6: Prezentace z internetových stránek Education Using PowerPoint

WEBOVÉ STRÁNKY GYMNÁZIA JAROŠKA

http://www.jaroska.cz/elearning/chemie/index.html

Gymnázium Brno tř. Kpt. Jaroše

Webové stránky školy, kde jsou ke stažení prezentace vytvořené vyučujícími. Prezentace obsahují obrázky, občas schémata. Neobsahují žádné aktivizační prvky. Graficky některé využívají barevnost, nebo zařazení obrázků. Potenciál prezentací z grafického hlediska rozhodně plně nevyužívají (ukázky z prezentací - obr. 7 a obr. 8). 

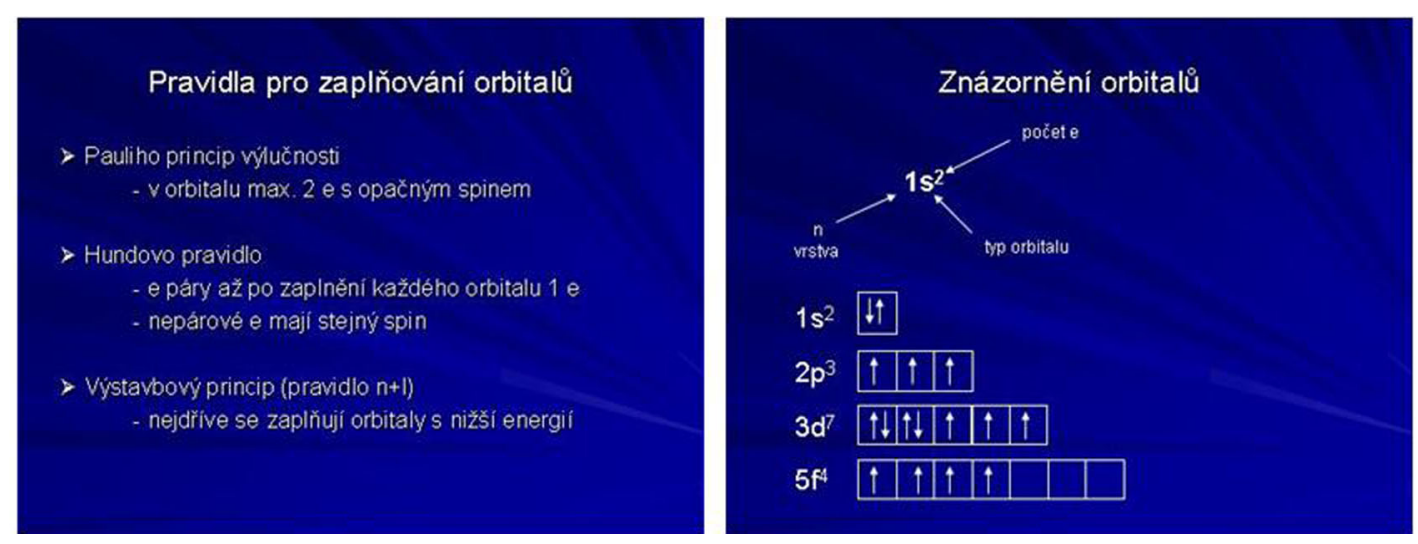

Obr. 7: Prezentace z internetových stránek Gymnázia Brno tř. Kpt. Jaroše
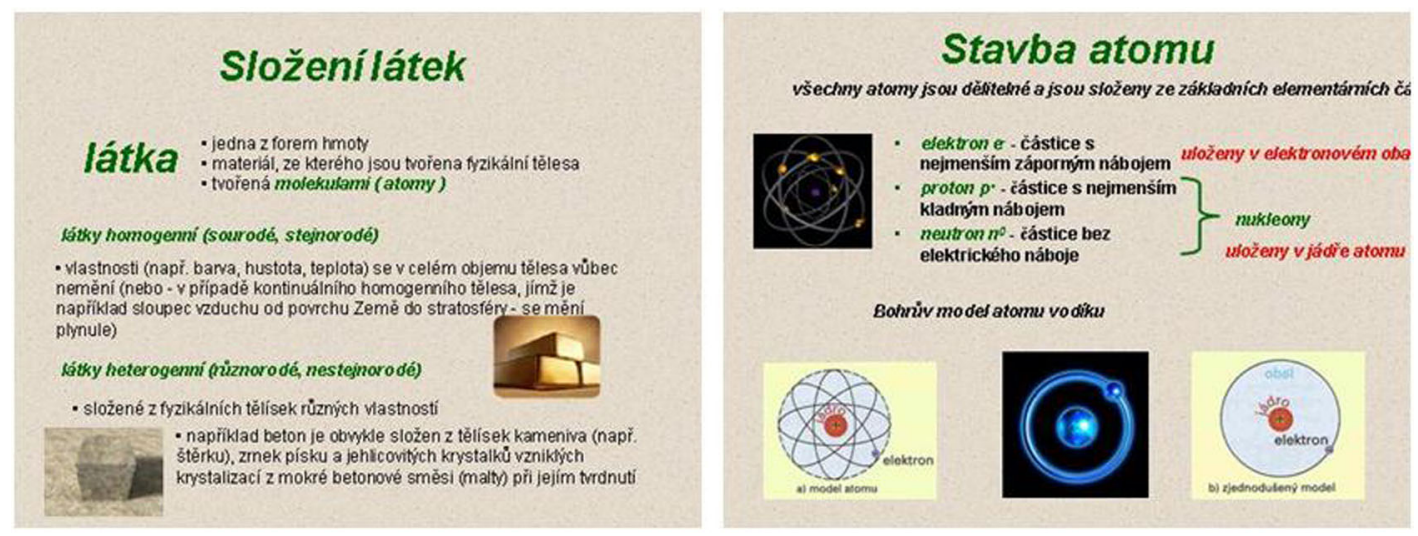

Obr. 8: Prezentace z internetových stránek Gymnázia Brno tř. Kpt. Jaroše

\section{METODICKÝ PORTÁL RVP}

http://rvp.cz/

Zdrojem různých materiálů určených pro výuku je portál Rámcových vzdělávacích programů. Zde lze nalézt i prezentace určené do výuky. Především se jedná o prezentace pro základní školu, v kterých je velmi často upřednostňováno zařazování obrázků a dalších grafických prvků oproti textům. Rovněž zde lze nalézt zařazování úloh včetně řešení. Z oblasti, na kterou se zaměřoval tento výzkum, tedy prezentace věnované učivu obecné chemie určené pro střední školy, zde nenalezneme takřka žádné materiály. Ukázka jedné prezentace je na obrázku 9.

\section{KVANTOVÁ ČÍSLA}

http://dum.rvp.cz/materialy/kvantova-cisla.html (obr. 9)

Autor: Kateřina Crháková

Prezentace je určena prvnímu ročníku čtyřletého gymnázia. Obsahuje základní poznatky o kvantových číslech a tvarech orbitalů, je doplněna i o několik př́kladů k procvičování elektronových konfigurací jak atomů, tak i aniontů a kationti̊. Prezentace obsahuje několik obrázků. Dále neobsahuje žádné další grafické prvky určené k podpoře srozumitelnosti učiva, a minimum aktivizačních prvků.

Lze shrnout, že prezentace, které lze volně stahovat z internetu a které se zabývají oblastí obecné chemie, málo kdy splňují požadavky, které byly v tomto výzkumu na didaktické prezentace kladeny. Z tohoto hlediska jsou na lepší úrovni některé prezentace $\mathrm{v}$ anglickém jazyce a prezentace určené pro základní školy. 


\section{Orbital s}

$>$ Orbital s $n=1 \Rightarrow l=0 \Rightarrow m=0$

> Má tvar koule, jejiž polomĕr se

s postoucí hodnotou n zvětšuje

> Kaṽdá hladina elektronového obalu

obsahuje pouze jeden orbital s

\section{Grafické znázornění orbitalus}

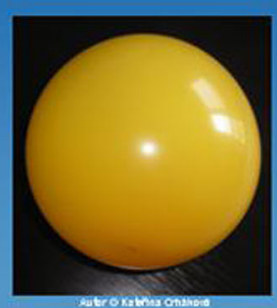

Kvantová čisla

Hlavní kvantové čislo - $n$

Vedlejül kvantové číslo - I

Magnetické kvantové čislo - m

Spinové kvantové ếislo - s

Stejnè lze popsat místo

nejpravdëpodobnềjühtho výskytu

elektronu v obaju.

Obr. 9: Prezentace z internetových stránek RVP

\subsection{DotazníKové ŠETřEní}

V této části výzkumu, která probíhala v letech 2006-2008, bylo předloženo učitelům středních škol 10 prezentací, které byly vytvořeny tak, aby obsahovaly aktivizující prvky a prvky graficky znázorňující učivo, z nichž každá byla určena pro jednu vyučovací hodinu, trvající 45 minut. Učitelé byli s obsahem a způsobem použití prezentací seznámeni v rámci půldenního semináře. Ke každé prezentaci dostali krátký text, který byl věnován obsahu a cílům prezentací a dále otázkám a úlohám, které jsou součástí prezentací. Všechny otázky a úlohy nabízely přímo v prezentacích autorská řešení.

Dotazníkového šetření se zúčastnilo 20 učitelů ze 17 středních škol (15 pražských a 2 z menších měst), kteří hodnotili možnosti využití prezentací ve 41 třídách s celkem 1107 žáky (maximální počet žáků ve třídě byl 30).

Předložený dotazník obsahoval 5 uzavřených položek a 7 otevřených. Soustředil se na otázky grafiky předložených prezentací, systém začleněných otázek a úloh a hodnocení efektivity výuky doplněné prezentacemi. Dále se učitelé v dotazníku vyjadřovali k efektivitě práce s předem připravenou prezentací, např́iklad z časového hlediska. Navíc dotazník obsahoval jednu otázku týkající se technické vybavenosti škol, aby bylo možno dát získané informace do souvislosti s technickými možnostmi ve třídách, kde byl výzkum prováděn.

Uzavřené položky sloužily k rychlejšímu, měřitelnému zhodnocení předložených prezentací. Otevřené položky byly určeny k mapování subjektivních názorů učitelů, kteří prezentace ve své výuce využívali. Výstupy z těchto otevřených položek byly považovány za hlavní výsledek tohoto výzkumu. Vyhodnocování otevřených položek dotazníku bylo prováděno postupnou kategorizací částí odpovědí respondentů. 


\subsection{DIDAKTICKÝ TEST}

K posouzení efektivity využití didaktických prezentací ve výukovém procesu bylo žádoucí porovnat míru osvojení učiva u žáků, kteří se zúčastnili výuky s použitím didaktických prezentací a u žáků, kteří se zúčastnili výuky bez didaktických prezentací.

Jedním z prostředků, který umožňuje zjištovat míru osvojení učiva, je stanovení její úrovně na základě dosažených výsledků žáků v didaktických testech.

Při tvorbě testu byly zvoleny typy položek, které lze zařadit mezi objektivně skórovatelné úlohy.

- Úlohy otevřené se stručnou odpovědí produkční, kdy má žák vytvořit a uvést vlastní krátké odpovědi (4 položky).

- Úlohy uzavřené s výběrem odpovědi, které se skládají ze dvou částí: kmenu úlohy (což je otázka nebo nabízený problém) a předkládaných odpovědí. Byla zvolena varianta čtyř nabízených alternativ odpovědi, z nichž pouze jedna je správná (15 položek).

- Úlohy uzavřené přiřazovací, které se skládají z instrukce, což je pokyn co a jakým zpơsobem má žák provést a ze dvou množin pojmů, obsahujících prvky, které k sobě žák přiřazuje podle zadané instrukce (4 položky: 3 položky).

Test obsahoval celkem 22 položek. Ve třídách testy zadávali sami učitelé. Součástí testu byly i písemné pokyny pro žáky. Žáci test vyplňovali po dobu 30 minut. Období zadávání testu se u jednotlivých učitelů lišilo, protože bylo dáno ukončením výuky daného tématu. Celkově probíhalo testování od listopadu 2009 do dubna 2010.

Testování se zúčastnilo celkem 225 žáků prvních ročníků čtyřletých, nebo pátých ročníků osmiletých gymnázií. Testována byla jednak skupina výzkumná (125 žáků), tedy žáci ze tříd, kde byly při výuce použity PowerPointové prezentace a potom skupina kontrolní (100 žáků), kde byli testováni žáci, kteří se účastnili výuky bez použití PowerPointových prezentací.

\section{VÝSLEDKY VÝZKUMU}

\subsection{DotazníKové ŠETŘENí}

Překvapivě dobře dopadly výsledky části dotazníku věnované technické vybavenosti škol. Všichni učitelé uvedli, že mají ve škole k dispozici nějaké technické zařízení, které je potřebné pro zařazení PowerPointových prezentací do výuky.

Další výsledky vyplynuly z uzavřených položek dotazníku. Celkově lze zhodnotit, že se učitelé vyjadřovali pozitivně k otázkám užité grafiky, k využití úloh a otázek v prezentaci, k využití schémat, obrázků a animací. Zásadní otázky, které si tento výzkum kladl, se týkaly vlivu prezentací na pozornost žáků a na porozumění učivu. Nejvíce bylo učitelů, kteří se domnívali, že se pozornost žáků při výuce doplněné prezentacemi zvýšila, nebo že prezentace neměly žádný zásadní vliv na pozornost žáků. Souhrn odpovědí na otázku, která se týkala ovlivnění porozumění učivu při výuce doplněné prezentacemi, dopadl velmi podobně.

Závěry otevřených položek dotazníku byly po provedené kategorizaci rozděleny do čtyř oblastí, do kterých byly názory učitelů nejčastěji směřovány: formát a uspořádání prezentací, vliv prezentací na učitele, vliv prezentací na žáky, vliv prezentací 
na výuku. V rámci jednotlivých kategorií byla vyjádření učitelů shrnuta do následujících formulací:

Formát a uspořádání prezentací: přínosné jsou snímky obsahující obrázky či animace, prŕliš mnoho textu na snímku ruší pozornost, příliš mnoho informací na jednom snímku snižuje míru porozumění učivu.

Vliv prezentací na učitele: zajímavější práce pro učitele, usnadnění práce učitele, lepší kontakt učitele s žáky, horší kontakt učitele s žáky.

Vliv prezentací na žáky: někteři žáci ztrácí pozornost, zvyšuje u žáků pozornost, u žáků dochází ke zvýšení zájmu, žáci jsou pasivní, pozitivně působí jako změna činnosti, výuka je pro žáky atraktivnější, usnadňuje žákům zapisování poznámek z výuky.

Vliv prezentací na výuku: výuka s prezentacemi šetří čas, výuka s prezentacemi je časově náročná, výuka je uspořádanější, výuka je názornější, prezentace jsou zpestřením výuky, výuku komplikuje špatná vybavenost učebny, výuku negativně ovlivňuje nutnost zatemnění učebny.

\subsection{DIDAKTICKÝ TEST}

Statistické porovnání dat z obou vzorků bylo provedeno programem Statgrafics Centurion XV. Ověřována byla nulová hypotéza $\mathrm{H}_{0}$, že výsledky testů výzkumné a srovnávací skupiny jsou stejné.

Pozorovaná hladina významnosti použitého Kolmogorov-Smirnov testu je $P=$ 0,176 a maximální vzdálenost distribučních funkcí je $D N=0,148$. Znamená to, že na hladině významnosti $\alpha=0,05$ není statisticky významný rozdíl v distribuci obou souborů a platí hypotéza $\mathrm{H}_{0}$. To tedy znamená, že nebyl nalezen statisticky významný rozdíl mezi efektivitou výuky s využitím PowerPointových prezentací a výukou bez nich.

\section{Diskuse}

Získané výsledky přinesly několik zajímavých informací. Jak již bylo řečeno, ve všech školách, kde bylo šetření prováděno, je technické vybavení potřebné k výuce s prezentacemi k dispozici. Náročnost přípravy na výuku a s tím i rozhodnutí učitelů, zda takový výukový prostředek použijí je přitom na dostupnosti tohoto zařízení v rámci školy přímo závislá. Komplikace může přinášet potřeba rezervace přenosného zařízení či třídy, která je $\mathrm{k}$ těmto účelům vybavená, zapojování přenosného zařízení či organizace skupin žáků, pokud se výuka bude odehrávat v jiné místnosti, než je běžné.

Odpovědi na otázky, zda výuka doplněná prezentací přispívá ke zvýšení zájmu žáků o učivo, zvýšení míry pozornosti a přispívá k lepšímu porozumění učivu, jsou složitější. Z výsledků uzavřených položek dotazníku i z reakcí učitelů v otevřených položkách plyne, že velká část z nich se domnívá, že zájem a pozornost žáků se zvyšuje. Je ovšem třeba říci, že zároveň často právě tito učitelé uvádějí pozitivní vliv prezentací v souvislosti se změnou činnosti žáků. Z toho lze soudit, že vyšší zájem může být často ovlivněn právě „novinkovým“ efektem, což znamená, že při dlouhodobější aplikaci výukového prostředku může docházet k opadnutí zájmu žáků. To ovšem neznamená, že to není pozitivní fakt a že by ho nebylo možno využít. Je ale zřejmé, že pokud by se prezentace staly každodenní součástí veškeré výuky tak, jak je tomu mnohdy již při přednáškách na vysokých školách, lze očekávat úpadek 
zájmu i pozornosti žáků. Přínos ke zvýšení efektivity výuky ve srovnání s jinými didaktickými prostředky by potom byl minimální.

Z výsledků otevřených položek dotazníku je vidět další zajímavý fakt. Od různých učitelů zde získáváme zcela protichůdné názory, např́klad co se týká kontaktu mezi učitelem a žáky. Z toho lze usuzovat, že nejen vnímání výuky je u různých učitelů jiné, ale nejspíše celá výuka s prezentací vedená různými učiteli bude vypadat jinak. Toto zjištění odpovídá obdobným výsledkům výzkumu prováděného na vysokých školách (Hardin, 2007). Můžeme tedy říci, že při použití stejného výukového prostředku nelze očekávat jednotné výsledky a dopady na edukační proces, protože zde hraje velmi výraznou roli schopnost učitele s tímto výukovým prostředkem pracovat, jeho předchozí zkušenosti s podobnými výukovými prostředky, jeho věk, zaměření a podobně.

Co se týká samotných prezentací, zde byly názory učitelů poměrně jednotné. Plyne z nich, že učitelé nepovažují za přínosné zařazovat do výuky prezentace, které obsahují pouze text, který je členěný a strukturovaný ve formě snímků a bodů na snímcích. Naopak za užitečné považují takové prezentace, které přinesou maximum vizuálních neverbálních prvků, jako jsou obrázky, animace, schémata apod. Dále z šetření vyplynulo, že je žádoucí, aby se v prezentacích vyskytovalo co možná nejvíce prvků, které podněcují žáky k činnosti, tedy zařazování úloh, otázek, neúplných vět či schémat, které lze doplnit apod. Prezentace připravené tradičně jako výkladové vedou spíše $\mathrm{k}$ pasivitě žáků než $\mathrm{k}$ jejich aktivní účasti na výuce.

Z výsledků didaktických testů, jejichž úkolem bylo především ověření efektivity výuky s využitím prezentací, nevyplynuly žádné výrazné rozdíly mezi zkoumanými a srovnávacími skupinami. Tento výsledek byl očekávatelný i vzhledem $\mathrm{k}$ výsledkům výzkumů, které se zabývaly efektivitou vysokoškolských přednášek doplněných prezentacemi (Bartsch, Cobern, 2003, Lowry, 1999, Susskind, 2008). Výsledky zkoumané i srovnávací skupiny zahrnovaly tř́idy s vynikajícími výsledky a třídy s celkově špatnými výsledky. Z toho lze usuzovat, že na efektivitu výuky nemá tak výrazný vliv použitý didaktický prostředek, ale především způsob, jakým dokáže učitel vybrané didaktické prostředky zapojit do procesu výuky. Tyto závěry odpovídají již výše citovanému výzkumu E. F. Hardinga (Harding, 2007).

Tyto didaktické testy ovšem nedokázaly zcela ověřit jeden z cílů této práce. Tím bylo připravit prezentace doplňující výuku obecné chemie, které pomohou žákům vytvořit si nadhled nad dalším učivem z oblasti anorganické chemie, organické chemie a biochemie a zvýšit kvalitu jejich znalostí a dovedností z obecné chemie tak, aby dokázali aplikovat toto učivo při studiu konkrétních chemických jevů. Tyto schopnosti žáků bude možné zjištovat až při dalším studiu chemie na střední škole. Ovšem i tato schopnost žáků závisí silně na osobě učitele a na tom, jak dokáže zapojit získané znalosti, vědomosti a dovednosti z obecné chemie do další výuky.

Na základě tohoto výzkumu lze říci, že výukové prezentace, které jsou dobře připravené, obsahují dostatek vizuálně názorných částí a prvků určených k aktivizaci žáků mají ve středoškolské výuce své místo. Pokud budou mít učitelé vhodné podmínky a technické zázemí, může mít tento didaktický prostředek pozitivní vliv na efektivitu výuky. Ovšem obecně takový závěr nelze vyslovit. Jednoznačné je, že pokud mají být prezentace užívány efektivně, pak je nutné střídat výuku doplněnou prezentací s jinými didaktickými prostředky a činnostmi žáků.

Z výsledků práce vyplývá jeden zásadní požadavek. Aby prezentace mohly přispět ke zvýšení efektivity výuky, je třeba, aby učitelé získali jednak dovednosti nutné $\mathrm{k}$ přípravě didaktické prezentace (tedy ne jenom technické dovednosti potřebné $\mathrm{k}$ práci s prezentačním softwarem), jednak aby získali dovednosti týkající 
se efektivního zapojení těchto didaktických prostředků do výuky, tedy např́klad, jak propojit výuku s prezentací s dalšími činnostmi žáků (̌̌̌šení úloh, práce s modely, referáty, vyhledávání informací apod.) a zároveň s dalšími činnostmi učitele (výklad, vedení diskuse, demonstrační pokus). V první řadě je třeba vůbec přesvědčit učitele, že toto propojení je možné a hlavně žádoucí. Je to samozřejmě spojeno i s nutností technické organizace vedení výuky. Například je třeba řešit, zda budu potřebovat také tabuli, zda mi plátno na promítání tabuli nepřekrývá, jak řešit zatemnění učebny, aby se v ní dalo ještě pracovat a podobně. Zde je třeba zdůraznit důležitou roli oborových didaktik, v rámci kterých by měli být budoucí, ale i současní učitelé v průběhu dalšího vzdělávání na tuto činnost připravováni.

Výzkum kromě odpovědí přinesl samozřejmě také řadu otázek, které by mohly být východiskem dalšího šetření. Vzhledem $\mathrm{k}$ tomu, že tento výzkum byl zaměřen především na názory vyučujících, bylo by do budoucna žádoucí zaměřit se na názory a zkušenosti žáků. Z rozhovorů vedených s učiteli během výzkumu vyplynulo, že žáci se $\mathrm{v}$ některých případech staví $\mathrm{k}$ prezentacím ve výuce dosti negativně. Bylo by proto zajímavé provést šetření, které by dalo do souvislosti postoje žáků s jejich dosavadními zkušenostmi s výukou doplněnou prezentacemi. Dále se v posledních letech objevil ve výuce další fenomén související s prezentacemi, a to jako forma žákovských referátů. I tato oblast by zasloužila další šetření z hlediska přínosu či negativních dopadů na žáka, který prezentaci vytváří, z hlediska schopností učitelů dát žákům patřičné instrukce a schopností hodnotit jejich výkon a podobně. Dále by bylo zajímavé provést srovnání názorů žáků a názorů učitelů na prezentace ve výuce. Podobné srovnání ve vysokoškolských podmínkách ukázalo, jak výrazně se pohledy těchto dvou skupin liší (James, Burke, Hutchins, 2006).

Lze předpokládat, že prostředky informačních a komunikačních technologií budou dále pronikat do výukového procesu a školy se budou v rámci možností snažit doplňovat a obnovovat technické vybavení. To je dáno i ekonomickým tlakem ze strany firem a komerční sféry na veškeré typy vzdělávacích zařízení. Proto je třeba, aby se odborníci z oblasti oborových didaktik snažili hledat vhodné způsoby využití těchto technologií tak, aby se uplatnily jejich možnosti a zároveň, aby byly pojmenovány a eliminovány jejich možné negativní dopady na edukační proces.

\section{ZÁVĚR}

Na základě tohoto výzkumu lze říci, že výukové prezentace, které jsou dobře připravené, obsahují dostatek vizuálně názorných částí a prvků určených $\mathrm{k}$ aktivizaci žáků mají ve středoškolské výuce své místo. Pokud budou mít učitelé vhodné podmínky a technické zázemí může mít tento didaktický prostředek pozitivní vliv na efektivitu výuky. Ovšem obecně takový závěr nelze vyslovit. Jednoznačné je, že pokud mají být prezentace užívány efektivně, pak je nutné střídat výuku doplněnou prezentací s jinými didaktickými prostředky a činnostmi žáků.

\section{LITERATURA}

BARTSCH, R. A., COBERN, K. M. Effectiveness of PowerPoint presentations in lectures: Computers $\&$ Education. 2003, Aug. 03, s. 77-86.

CLARK, N. Awesome science teacher resources. [on-line]. [cit. 2010-03-12].

Dostupné z: 〈http://www.nclark.net/Chemistry〉 
COSTELLO, K. Chemistryland. [on-line]. [cit. 2010-04-15].

Dostupné z: 〈http://www.chemistryland.com/home.html〉

CRAIG, R. J., AMERNIC, J. H. PowerPoint Presentation Technology and the Dynamics of Teaching. Innovative Higher Education. 2006, Oct 2006, p. 147-160.

CRHÁKOVÁ, K. Kvantová čísla. Metodický portál : Digitální učební materiály [on-line]. 26. 08. 2010, [cit. 2010-11-14].

Dostupný z : 〈http://dum.rvp.cz/materialy/kvantova-cisla.html〉. ISSN 1802-4785.

ČTRNÁCTOVÁ, H. Učební úlohy v chemii. 1. díl. Praha : Karolinum, 1998.

ČTRNÁCTOVÁ, H. Výběr a strukturace učiva chemi. Praha : SPN, 1981.

EXNAR, P. [on-line]. [cit. 2010-03-12].

Dostupné z: 〈http://www.fp.vslib.cz/kch/exnar/fs/prezentace/〉

GIER, V. S., KREINER, D. S. Incorporating Active Learning with PowerPointBased Lectures Using Content-Based Question. Apr 2009, Teaching of Psychology, vol. 36, no. 2, p. 134-139.

HARDIN, E. E. Technology in Teaching: Presentation Software in the College Classroom-Don't Forget the Instrukto. Teaching of Psychology. 2007, vol. 34, no. 1, p. $53-57$.

Chemie. [on-line]. [cit. 2011-04-12].

Dostupné z: 〈http://www.jaroska.cz/elearning/chemie/index.html〉

JAMES, K. E., BURKE, L. A., HUTCHINS, H. M. Powerful or Pointless? Faculty versus Student Perceptions of PowerPoint Use in Business Education. Business Communication Quarterly. 2006, vol. 69, no. 4, p. 374-396.

LOWRY, R. B. Electronic presentation of lectures - effect upon student performance. University Chemistry Education. 1999, no. 3 1, p. 18-21.

PRIESTLY, W. Instructional Typography Using Desktop Publishing Techniques to Produce Effective Learning and Training Material. Australian Journal of Educational Technology. 1991, vol. 7, no. 2, p. 153-163.

RICHARDS, W. Education Using PowerPoint. [on-line]. 2011 [cit. 2010-05-04]. Dostupné z: 〈http://www.educationusingpowerpoint.org.uk/〉

SCHNEIDER, J. Chalkbored. [on-line]. 2009 [cit. 2011-02-10].

Dostupné z: 〈http://www.chalkbored.com〉

SUSSKIND, J. E. Limits of PowerPoint's Power: Enhancing Students' Self-Efficacy and Attitudes but Not Their Behavior. Computers and Education. 2008, v. 50, no. 4 May, p. $1228-1239$.

RNDr. Klára Urbanová, Ph.D. - E-mail: urbanklara@seznam.cz

Malostranské gymnázium, Praha 1, Česká republika 